\title{
Legal Enforcement on Environmental Impact of Palm Oil Plantation of Merauke District
}

\author{
Marlyn Jane Alputila ${ }^{1, *}$, Rullof F. Y. Waas ${ }^{1}$, Erni Dwita Silambi ${ }^{1}$, Yuldiana Zesa Azis ${ }^{1}$, and Mulyadi Alrianto \\ Tajuddin ${ }^{1}$ \\ ${ }^{1}$ Faculty of law, Musamus University, Merauke- Indonesia
}

\begin{abstract}
Merauke City is one of the cities in Papua which has 4.6 million hectares consisting of 3.1 million hectare for forest coverage and the rest is 1.5 non-forest coverage. Around $66 \%$ forest coverage consists of primary forest, high-density secondary forest, low-density secondary forest, primary swamp forest, secondary swamp forest, eucalyptus/acacia forest, primary mangrove forest, and secondary mangrove forests. Merauke City is one of the place which has a great potential to maintain and sustain ecological system with its vast territory and its evergreen forest which people keep its sustainability. However, the government and some companies expanding their business take a toll for the balance of the nature, since some of the forest areas are cut down and the industrial waste affects the ecosystem. Some territories in Merauke become heavily polluted from the wastes. One of the pollution cases is from six palm oil companies which has polluted some forests in Merauke, Papua. The companies responsible for the decreasing environmental condition are operating in Malind Bian such as PT Dongin Prabhawa ( Korindo Group), PT Bio Inti Agrindo ( Korindo group), PT Central Cipta Murdaya (CCM), PT Agriprima Cipta Persada, PT Hardaya Sawit Papua and PT Berkat Cipta Abadi. The method is of this study is normative legal approach. The result of this study reveals that the government are advised to include the society and the locals to make a decision and to find a good solution for the environment which has been sustaining their life. This may resolve the problem between the palm oil company, the government, and the society to uphold a new law. The government should be strict to set rules in order to be beneficial not only for the companies, but also for the society, the government, and the environment in Merauke City. When the law has been issued, the companies indicated to be violating certain set of rules regarding environmental pollution and contamination, can be evaluated and revoked of their warrant to do business in Merauke. This will be a good solution to make sure the sustainability of the environment, forests, and the society depending on it.
\end{abstract}

Keywords: Environmental pollution; Law upholding; Palm oil.

\section{Introduction}

Indonesia is one of the developing countries that is still very active in the process of planning and development development. In order to implement environmentally sound development as a conscious effort and plan to manage resources wisely in sustainable development to improve the welfare and quality of life, it is necessary to maintain harmony between various businesses and activities.

Every effort and activity basically has an impact on the environment that needs to be analyzed since the start of its planning, so that negative impact control measures and the development of positive impacts can be prepared as early as possible. An analysis of the environmental impacts is required for the decision-making process on the implementation of business plans and activities that have significant and significant impacts on the environment.

In the case of law enforcement is one of the problems that have been until now is very interesting to be studied and known, this is because law enforcement plays an important role in the peace and welfare of human life. But over time and technological advances coupled with human behavior is less responsible for nature sehing so many natural damage everywhere sehinnga require law enforcement by conducting an Analysis of the environmental impact (AMDAL) which is a study of the major and important impact of a business and planned activities on the environment necessary for the decision-making process on the operation of a business or activity. Amdal is a tool for planning preventive actions against environmental damage that might be generated by a planned development activity.

In the case of enforcing the law in the environmental field, the laws and regulations relating to the environment namely Law No. 32 Year 2009 on Environmental Protection and Management regulates sanctions to parties proven to violate the enforcement of environmental law which can be divided into three parts: 1) enforcement of environmental law related to state

Corresponding author: marlyn@,unmus.ac.id 
administrative law / administration, 2) enforcement of environmental law related to civil law, 3) enforcement of environmental law related to criminal law. [1](Unification Journal)

An analysis of environmental impacts should be undertaken for companies whose activities are expected to impact the environment for a long time. So that there should be regulations or laws that regulate it, this is done so that the quality or ecosystem of the environment is not damaged or polluted because of the company that misuses his permission. Business owners who do not prepare environmental impact analysis (EIA) then all business permits will be complicated or can be prosecuted by law.

The need to create environmental impact analysis is an effective way to compel corporate owners to keep an eye on the environmental impact. The impact of a business activity should be predicted both the positive impact and the negative impact of the business activity before the business activity is done with the analysis of the law enforcement must be seen whether it is running well or not.

The most common environmental problems are: 1) land degradation due to deforestation, illegal logging, land conversion for plantation and industrial crops, oil, industrial and residential mining; 2) abrasion of the riverbank due to the traffic of large and fast vessels; 3) river catchment by high erosion, abrasion and sedimentation; 4) interruption of the surface water flow pattern due to land conversion, the presence of harbor, dock, logpond; 5) degradation of water quality due to industrial liquid waste disposal, domestic ship water ballast discharge, and domestic solid waste disposal. [2](Unification Journal)

Merauke regency is one of the districts in Papua with 4.6 million hectares of land comprising 3.1 million hectares of forest cover and 1.5 million non-forest cover. Forest cover ranges from $\pm 66 \%$ consisting of primary forest, high density secondary forest, low density secondary forest, primary swamp forest, secondary swamp forest, eucalyptus / acacia forest, primary mangrove forest and secondary mangrove forest. [3](Samuelerino Tahiya DKK, land use planning strategy of Merauke Regency 2017)

With a vast area and coupled with the condition of the forest is very preserved the Merauke District is one of the areas that have the potential to support environmental sustainability. However, with the cooperation of local governments and companies that want to develop their business in Merauke this brings an unfavorable impact because with the activities carried out by these companies mangakibatkan some areas in Merauke District experiencing environmental pollution.

This has an impact on local wisdom that has been upheld by local indigenous peoples. One example of the case is that six oil palm companies have polluted the forest in Merauke district, Papua. Large-scale oil palm companies operate in the Malind Bian area of Merauke, namely PT Dongin Prabhawa (Korindo Group), PT Bio Inti Agrindo (Korindo group), PT Central Cipta Murdaya (CCM), PT Agriprima Cipta Persada, PT Hardaya Sawit Papua and PT Berkat Cipta Abadi. These companies operate on a large scale but over time there are indications of environmental pollution that occurred this is known from the investigation results of environmental pollution that resulted in three rivers that exist around the company experienced penvemaran in the form of water change color and emit odor, this has an impact on the need for clean water needed by the surrounding residents who live around the river or river. (Musa Abubar [4](Contributor Papua) six palm companies pollute the river)

This is the background to how the local government to observe and supervise the companies by enforcing the law on environmental impacts that occurred in Merauke District. So the researcher conducted this study research can increase knowledge and understanding of the dangers posed by violation of the law in the environmental field towards the welfare and health of the merauke distric community.

\section{Method}

The method used in this research is using the normative juridical method where this study aims to know and examine the rules, legislation or policies related to the environment and plantation and law enforcement on the protection and management of the environment that is Law No. 32 Year 2009 and see the problems that occur as well as the impact of law enforcement.

\section{Discussion}

\subsection{Impact of Environmental Pollution on Palm Oil Plantation Area of Merauke Regency}

In terms of improving the welfare and food strength in Merauke, some of the areas that are one of the largest regencies in Papua already have a project by making them as agricultural land or industrial estates. Thus there are several companies that build their industrial business in Merauke Regency. One of the many forms of business in Merauke District is Palm Oil Plantation. Plantation is one form of business that is very popular today because the plantation business proved sufficient to survive the storm of the monetary crisis that once hit our country. So the Indonesian government is of the opinion that the plantation is one form of planned, open, integrated, professional and responsible natural resource management and one of the most rapid development of oil palm plantations.

In article 2.3,4 of Act No. 18 of 2004 on Plantations, it is stated that Plantations are organized on the basis of: [5](M Hadin Muhjad.2015)

1. Benefits and sustainability

2. Integration

3. Togetherness

4. Openness, as well as

5. Justice

From the side of the plantation economy can function as an increase in the welfare of the community, and from the socio-cultural side can be a unifier and 
strengthen the community and nation. One of the objectives of the plantation is to increase work opportunities and provide foreign exchange input for the country. But over time with the increasing number of plantation business, one of them is oil palm plantation, there are many violations of the law that many polluted rivers and the people who inhabit the area around oil palm plantations begin to be affected by the pollution that occurred in their area.

In 2010, 46 companies have been prepared to invest in agriculture and plantations in Merauke Regency, in the Merauke Integrated Food Estate And Energy (MIFEE) program. All these companies have obtained a location permit with a total of 228,000 hectares of prepared land. The companies are investing in sugarcane, palm and rice plantations such as rice. [6](Https://lifestyle.kompas.com/read/2011/08/05/16120 566/46.perusahaan.investasi.di.mifee).

The magnitude of Indonesia's palm oil productivity results from wetland use that continues to increase in number each year. Export opportunities and the availability of market land trigger business actors to continue to expand land in instand and not on wellutilized land. So the fact is that various forms of transfer function cause the decline of strategic function of peat land, so that it increases the area of critical land. The impact of palm oil plantation development that is large enough to the environment such as the disappearance of natural vegetation and the unique flora and fauna and will become very dangerous when experiencing a total extinction in most areas in Indonesia. [7](H. M Hadin Muhjad, 2015)

However, in 2012 there are several cases that occur that there are environmental pollution that resulted in about six (6) Palm Oil companies have mencamari environment that is part of the Merauke Integrated Food Energy And Estate (MIFEE) project in Merauke, Papua. Pollution occurs in three rivers: Kum River, Bian River and Maro River. As a result of the company's waste pollution, fish such as cork and mujair fish began to die, and other than that of 46 companies granted permission from the government then 10 of these companies are engaged in oil palm plantations. this is written by Musa Abubar (contributor of Papua) December 25, 2012.

[8](http://www.mongabay.co.id/2012/12/25/6-companysawit-femari-sungai-di-merauke/)

This is one of the impacts of environmental pollution by waste from companies running their business in Merauke Regency. In addition, there are also some cases that cause environmental pollution.

According to Carlo Nainggolan from Sawit Watch, the results of the investigation of the impact of environmental pollution caused by waste caused the contamination of river water, causing the river water to change color and give off unpleasant odor so that residents who live around lack of clean water. In addition, indigenous peoples as owners of ulayat rights feel restless because there are companies that run the company's activities by clearing the land through the way of burning the forest this cause the cultural sites around where the company became threatened so that the natural wealth will be lost. This resulted in anxiety for the Malind Bian community because the forests were heavily logged for the MIFEE project by clearing forest land without considering the impact it would have on the future.

While regarding the contract period that became the problem that is from the right side of business (HGU) which is regulated in Law no 5 of 1960 Basic Agrarian Law that is in article 29 Hak Guna Usaha can be given a maximum of 25 years but if the company with certain needs then can be extended to a maximum of 35 years. Oil palm plantation company which is part of MIFEE Project as many as 10 companies namely PT. Dongin Prabhawa (Korindo group) PT. Papua agro Lestari, PT. Bio Inti Agrindo (Korindo Group), PT. Mega Surya Agung, PT. Hardayat Sawit Papua, PT. Agri Nusa Persada Mulia, PT. Central Cipta Murdaya (CCM), PT. Agri Prima, PT. Cipta Persada and PT. Thanks to Cipta Abadi. [9](Http://www.mongabay.co.id/2012/12/25/6company-sawit-femari-sungai-di-merauke/)

These companies actually have owned and have made an analysis of the environmental impact that will occur but in the process of running the company business owners are no longer pay attention to the consequences caused because they think have paid land compensation. But in reality the compensation provided is also not in accordance with the expectations of indigenous peoples and not in accordance with the agreements that have been made before. This is what causes residents around the settlements of oil palm companies feel disadvantaged because there are many environmental pollution that makes them difficult in finding food and in getting clean water.

With the pollution occurring, the local indigenous community of Malian Bian indigenous people urged the Government to immediately act decisively by revoking or canceling the business permit from companies that have polluted the environment because in addition to polluting the environment due to which has been caused the destruction of customary forest since formerly well preserved by indigenous peoples.

According to Koentjaraningrat (1994) there are four main targets proposed for developing Papuans:

1. Increasing human resources by improving the health and nutritional quality of the population

2. Policies from above that should not ignore the interests of indigenous peoples, but should always be carried out in conjunction with development policies approaching them from below

3. All development project plans should always be prepared with in-depth study of the sociocultural conditions of the local population

4. Changing the attitude of non-Papuan Indonesians who still look down on the Papuans and consider them primitive, lazy, drunk and undisciplined. [10](miffe-book-resJournal)

Based on what Koentjaraningrat said, in terms of community development, especially indigenous Papuan people should in taking the policy is expected to involve and engage indigenous peoples this is very helpful so that people can participate decide the best for their 
continuation of life. This is the basis for governments as policy makers and entrepreneurs to be able to engage indigenous peoples from the initial process of environmental impact analysis so that environmental permits can be granted to the granting of business licenses and replacement processes or land compensation costs incurred. Whether it's about the land acquisition area, the process up to the replacement loss. So the most important in avoiding any damage and environmental pollution is the cooperation and openness between government, business groups and society.

\subsection{Law enforcement of environmental impacts based on legislation}

Law enforcement is one of the means in solving all problems that occur. According to Satjipto Rahardjo law enforcement is a process to realize the wishes of the law into reality. [11](Satjipto raharjo, 1983). In the case of law enforcement there are some very important elements of the element of law (substance), elements of law enforcement (strucstur) and also elements of the culture of society itself. Law enforcement is a process whereby the rules are created by the authorities and the rules must have content and content that is in accordance with the needs of today's society so that the rule of law can function and run well. The contents of the law should contain very clear rules. After the existence of clear rules then required a good legal structure and good in the process of enforcing these rules because it is not enough with only good rules but it requires the enforcement of good implementing officers as well, after that see the culture of the community in enforcement and enforcement.

In the case of law enforcement can be done with Preventive effort is the process of prevention, this prevention process can be done by how to inform about the rules to the public. By making preventive efforts to control the environmental impacts in addition to socialization of the rules of the environment should also be maximized supervision efforts are done optimally and also in the process of granting business license. However, if there has been pollution and damage to the environment, a clear, firm and comprehensive legal system should be developed.

Law enforcement in Law No. 32 of 2009 on Environmental Protection and Management has minimum rules of a criminal sanction as well as the minimum rules of sanctions as well as in its enforcement of enforcement of environmental criminal law also always apply the rules of criminal sanctions to be applied at the very end or known by the name ultimum remedium principle (criminal is the last resort) after the existence of administrative sanctions first.

To overcome and prevent an environmental pollution there are actually efforts that can be done so as not to happen things that are not desirable to the ecosystem of our environment.

There are several instruments of prevention and / or environmental damage contained in Article 14 of Law
No. 32 of 2009 consisting of[12] (Hadin Muhjad, 2015. 37):

a. Strategic Environmental Review

b. Spatial

c. Environmental Quality standards

d. The standard criteria for environmental damage

e. Amdal

f. UKP-UPL

g. Permission

h. Environmental economic instruments

i. Environmental legislation

j. Environment-based budgets

k. Environmental risk analysis

1. Environmental audits

$\mathrm{m}$. Other instruments in accordance with the needs and / or the development of science.

In addition to environmental pollution prevention measures, other efforts should be made optimally through environmental impact analysis as well as business licensing. In the environmental impact analysis (EIA) is done before the granting of the permit is done because environmental impact analysis (EIA) is one of the requirements that should be prioritized if a company engaged in the field of plantation will make a business. In the case of environmental impact analysis (AMDAL) is also a form of prevention against environmental pollution because in the process of compiling environmental impact analysis (AMDAL) documents must be done well because in the presence of good environmental impact analysis with the existence of sanction if violating the provisions of Amdal then a business or company may obtain an environmental permit. In addition to environmental impact analysis, what should be considered by the local government is the business license that will be given to companies that will run their business. Therefore, licensing issues are included in preventive efforts which in preventing environmental pollution the government can conduct an optimal supervision on the granting of business licenses, especially the granting of licenses to the company. But if the environmental pollution has occurred then will be applied repressive efforts where the rule of law must be executed firmly, clearly and accurately targeted and thorough by involving all law enforcement officers something with the rules of the applicable legislation so as to provide a legal certainty.

In the event of an environmental impact due to oil palm plantations, the utilization of wetland uses for oil palm plantations shows that wetlands are the target of palm oil plantation business actors. The issue between wetlands or mineral land has not become a matter taken into account by business actors, the dominating dimension of this time is the licensing from the government to be the most important aspect because in Indonesia is still doing the practice of opening the expansion of land with many permits issued certainly no place for business actors other than take the initiative is in the wetlands [13](HM Hadin Muhjad, 2015. 198)

Efforts Law enforcement based on legislation can be divided into 2 ie preventive efforts and repressive efforts. 


\section{a. Preventive Efforts}

What is meant by preventive efforts is prevention efforts before a crime, crime or violation occurs. so that included in prevention preventive effort against environmental pollution is effort to control of environmental impact by optimizing all instrument of supervision and permit. Supervision is a preventive effort in the context of controlling environmental impacts. Supervision in the concept of environmental law is the supervision included in the concept of administrative law because the supervision here includes the authority of the government which is continuous as a result of the issued permits.

b. Repressive Attempts

In the framework of environmental law enforcement there are administrative sanctions, namely article 25-27 of Law No. 32 Year 2009 on the Law of Protection and Management of Living Environment.

Article 25 of Law No. 32/2009 on Environmental Protection and Management Law provides the basis of authority to the Governor / Regent / Mayor in accordance with the scope of their respective authorities to impose administrative sanctions in the form of governmental coercion (bestuursdwang) to the party responsible for the business and / or activity business. Faced with coercion from the government, the responsible business or business activity may take action:

1. Prevent and terminate the occurrence of violations and overcome the consequences of an infringement of the safeguard requirements as reflected in environmental legislation and licensing.

2. Carry out rescue, mitigation and recovery measures as a result of an infringement of the safeguard requirements as reflected in environmental legislation and licensing at the expense of the person in charge of the business / activity. Instead the person in charge of the business / business activity can make payment of a certain amount of money. [14](H. M.Hadin Muhjad, 2015. 200-204)

In addition to administrative sanctions, the government, in this case authorized officials may impose administrative sanctions namely revocation of business licenses.

And in law enforcement efforts on the environmental impacts of oil palm plantations in Merauke District, the government as the holder of power and policy givers must make a selection to the companies that will invest in Merauke regency and if already invested and have indicated pollution

\section{Conclusion}

In adopting policies it is desirable to involve and engage indigenous peoples this is of great help so that the community can participate in deciding the best for their continued existence. This is the basis for governments as policy makers and entrepreneurs to be able to engage indigenous peoples from the initial process of environmental impact analysis so that environmental permits can be granted to the granting of business licenses and replacement processes or land compensation costs incurred. Whether it's about the land acquisition area, the process up to the replacement loss. So the most important in avoiding any damage and environmental pollution is the cooperation and openness between government, business groups and society.

And in law enforcement efforts on the environmental impacts of palm oil plantations in Merauke District, the government as the holder of power and policy giver must make selection to the companies that will invest in Merauke regency and if already invested and has been indicated to pollute the environment then the government should review the business licenses of these companies so that the lives of local communities or indigenous peoples can be well protected.

\section{References}

1. F. De Lillo, F. Cecconi, G. Lacorata, A. Vulpiani, EPL, 84 (2008) 1. H.M Hadin Muhjad, enviromental law an introduction to the context, Genita Publishing.2015

2. Unification Journal, ISSN 2354-5976 Vol. 03 Nomor 01 Januari 2016

3. Law No 32 Year 2009 on the Law of Protection and Management of Living Environment.

4. Samuelerino Tahiya DKK, land use planning strategy of Merauke Regency 2017

5. https://ifestyle.kompas.com/read/2011/08/05/1 6120566/46.perusahaan.investasi.di.mifee

6. http://www.mongabay.co.id/2012/12/25/6perusahaan-sawit-cemari-sungai-di-merauke/ miffe-buku-res-Jurnal

* Corresponding author: marlyn@unmus.ac.id 